Monika Gizynska, Dr iur.

University of Warmia and Mazury in Olsztyn, Poland

\title{
METHODS OF INCREASING VOTER TURNOUT IN THE CONTEXT OF ITS DECLINE AND LOW CIVIL CULTURE
}

\begin{abstract}
Summary
The article presents selected issues related to realization of the Principle of the Sovereignty of the Nation, the institution of voting and voting turnout. The author tries to answer the question: how to increase voter turnout in the context of its decline and low civil culture? The article explores the methods of increasing voter turnout, such as compulsory voting, canvassing, creating well-informed voters, the value of online relationships in spurring people to vote.
\end{abstract}

Keywords: voter turnout, diminishing of attendance, voting, increasing voter turnout, elections

\section{Introduction}

The article presents selected issues related to realization of the Principle of the Sovereignty of the Nation, the institution of voting and voting turnout. The article provides an answer to the question: how to increase voter turnout in the context of its decline and low civil culture? The current text presents methods of increasing voter turnout, such as compulsory voting, canvassing, creating well-informed voters, the value of online relationships in spurring people to vote.

The point of departure should be that the concept of democracy is governed by three principles: the principle of equality of all citizens before the law $^{1}$; the principle of constitutional rights of the individual towards the $s^{2} \mathrm{e}^{2}$; the principle that

1 Human Rights Committee determined that together with equality before the law and equal protection of the law without any discrimination, constitute a basic and general principle relating to the protection of human rights. CCPR General Comment dated 10 November 1989 No. 18. Available at: https://www.refworld.org/docid/453883fa8.html [last viewed January 14, 2020]. Also, the Polish Constitutional Tribunal determined the essence of the formal equality, which states that all public law entities distinguished equally by a given essential feature (relevant), shall be treated equally. The judgement of the Polish Constitutional Tribunal of 9 March 1988, Ref. No. U $7 / 87$.

2 The Human Rights Committee has stated that the citizen's right to take part in the conduct of public affairs includes constitutional processes. It has also recognized that the requirements of this right are met as long as important groups in society are represented and can participate. Human Rights Committee Communication of 30 January 1986 in case Marshall v. Canada (application No. 205/1986). 
the nation is represented by an appropriate state authority ${ }^{3}$. Democracy is based on the principle of the participation of society (nation) in the creation of the state, expressed mainly in the form of legislative acts adopted by the parliament, that is, a body consisting of representatives expressing the political will of the majority of citizens. Therefore, the parliament elected by general election expresses the majority view and creates the will of the state. Democracy is to ensure the freedom and equality of all citizens by that, to the same extent, each of them participates in creating the will of the state.

\section{Elections as a part of the representative system of democracy in a state and realization of the principle of the sovereignty of the nation}

Elections are a part of the system of democracy as the basic form of political governance in a state and realization of the principle of the sovereignty of the nation. By voting, representative bodies are composed, and representatives are entrusted with their mandate. The act of election is a process by which representative bodies are appointed. The act of voting and the principle of general election are related to the act of election. This is an expression of the principle of sovereignty of the nation. This is so, because in the system of representative democracy, the right to participate in composing the bodies of government is the main form by which citizens as a whole may influence public affairs ${ }^{4}$.

While the principle of general election has been formally accepted in democratic countries, we should stress that the actual participation of voters in the act of voting, or rather the lack of that participation, raises the question of whether voting is to be treated as a right or obligation.

It is worth noting here, that the decrease in voter turnout in many countries also in countries of well-established democracies, is very dangerous for the existence of the democratic system, because, in fact, it can mean delegitimization of the system. In the majority of democratic countries, active participation of citizens in the political life of their national communities is currently much needed. The above is related to increasing citizens' inaction and indifference to political affairs of the state, which, in turn, is reflected in a declining rate of electoral participation. The latter undoubtedly poses a threat to the system of democratic governance and the very idea of democracy, which in itself is not perfect, and the existence of which may be measured by the participation of citizens in political decision-making processes through participation in political elections. Democracy, and, in consequence,

For parliaments to be truly representative, elections must be free and fair. Citizens must have access to information about parliamentary proceedings, legislation, and policy, and be able to engage in continual dialogue with parliamentarians. Global Parliamentary Report: The Changing Nature of Parliamentary Representation, Denmark: UNDP/IPU, 2012, p. 9.

4 See Robbins J. S. Introduction: Democracy and Elections. Fletcher Forum of World Affairs, Vol. 21, No. 1, 1997, pp. 1-14. 
active civil participation in the political life of the state, is accepted in most of these countries. It should be emphasized that the reports on the level of voter turnout record global trend of decline in participation ${ }^{5}$.

\section{Various institutions as a remedy for decreasing voter turnout}

The decreasing voter turnout raises the question of how to remedy it. The representative system in its current form does not ensure good functioning of democracy. Many countries try to prevent the decrease in voter turnout. There are many methods for addressing this issue. It should be emphasized that the catalogue of guarantees of the principle of general election can be expanded but it is already very well developed (non-working day, opening hours of polling stations, voting circuits (permanent and separate), the possibility of voting in elections by citizens residing outside the country, register and list of voters, election protest, certificate of voting at the place of residence, or the use of alternative methods of voting, i.e., postal voting, electronic voting, proxy voting). However, the question arises whether the use of an increasing number of guarantees and the use of ever new information technologies will increase the participation of citizens in democratic processes? Furthermore, should the introduction of legal regulations that stipulate a mandatory participation in elections, i.e., normative regulation of compulsory voting be considered?

\subsection{Compulsory voting}

The institutional introduction of compulsory voting is undoubtedly the easiest and fastest way to increase voter turnout. It seems that the introduction of this institution to national legislation would provide the most significant benefits to emerging and underdeveloped democracies, where the widespread opinion that one's own vote has very little impact on the final result of election and public affairs is the basis for the electoral passivity of society. In this perspective, the legal obligation of voting would first develop in an individual a sense of "service" to the state, consisting in regular participation in elections of representatives appointed to exercise power, and then would teach a citizen a minimum civic commitment to the state, i.e., participation in the election of authorities.

Currently, the institution of compulsory voting is used in 28 countries (Belgium, Cyprus, Greece, Luxembourg, Turkey, Argentina, Bolivia, Brazil, Chile, Dominican Republic, Ecuador, Guatemala, Honduras, Costa Rica, Mexico, Panama, Paraguay, Peru, El Salvador, Uruguay, Venezuela, Australia, Fiji, Laos, Nauru, Singapore,

Statistics available at: https://www.idea.int/data-tools/question-view/521 [last viewed October 25, 2019]. 
Thailand, Egypt $)^{6}$. The research demonstrated the fact that where the institution of compulsory voting was implemented in the legal system, it has managed to play its role and formed an effective means of increasing voter turnout; in other words, mobilizing eligible citizens to actively participate in elections. In countries with compulsory voting systems, the turnout is approximately by $20 \%$ higher than in those without such regulation.

If considerable participation of voters in general and equal suffrage is a measure of democracy, then introduction of legal provisions the elections that cause the activation of civil society and increase its active participation in the election is absolutely democratic, and compulsory voting should be treated as an acceptable institution, perceived as a medial, preventive and democratic system-reforming instrument. It should be noted, however, that for all those who consider electoral participation as the right of an individual, and not his/her duty, compulsory voting will always be an undemocratic institution.

\subsection{Canvassing}

Activation of voters consists of measures aimed at mobilization of the electorate and a greater number of participants in elections (to increase voter turnout). This activization can take place with the help of institutional or propaganda factors. Institutional factors include all the legal mechanisms that directly or indirectly augment voter turnout ${ }^{7}$. An important role in the mobilization of voters is also played by properly prepared long-term propaganda campaign with a goal to stimulate voters' interest in the election and persuading them to participate in the act of voting. It mainly includes the following measures: information campaigns, in which voters are informed about the elections themselves, the voting method and the rules of the electoral process; promotional campaigns aimed at explaining the sense and effects of elections; civic campaigns; educational programs; organization of primaries; material incentives (lotteries, gifts) ${ }^{8}$.

6 For more on a compulsory voting, see: Giżyńska M., Polaczuk P. Compulsory voting: is possible in today's Poland? Studia Politologiczne, Vol. 32, 2014, pp. 301-313; Kato K. Evaluating Compulsory Voting: Australia in Comparative Perspective. Ann Arbor: ProQuest LLC, 2014, p. 210; Power T. J. Compulsory for Whom? Mandatory Voting and Electoral Participation in Brazil 1986-2006. Journal of Politics in Latin America, Vol. 1, 2009, pp. 97-122. Available at: http:// www.jpla.org/ [last viewed October 20, 2019]; Swenson K. M. Sticks, Carrots, Donkey Votes, and True Choice: A Rationale for Abolishing Compulsory Voting in Australia. Minnesota Journal of International Law, Vol. 16, 2007, pp. 529-552; Hill L. Compulsory Voting in Australia: A Basis for a Best Practice Regime. Federal Law Review, Vol. 32, No. 3, 2004, pp. 479-498; Matsler S. Compulsory Voting in America. Southern California Law Review, Vol. 76, No. 4, 2003, pp. 953-978.

7 This includes: compulsory voting, availability and opening hours of polling stations, election date, the existence of alternative ways of voting, type of electoral system.

8 See Andre A., Depauw S., Deschouwer K. Issue Uptake in the Shadow of Election. In: BetweenElection Democracy: The Representative Relationship After Election Day, Esaiasson P., Narud H. M. (eds.), ECPR Press, 2013, pp. 53-75. 
Therefore, improving the representativeness of the electorate and knowledge about strategies at stake may be a more important goal than dramatical increase of overall turnout. The most traditional way to get people out to vote is activization by volunteers or paid canvassers hitting the streets, talking to people on the streets, and going door to door to spread information about the elections 9 . Young and/or firsttime voters may not be familiar with the voting procedure or the candidates. In that case, showing or sending them a sample ballot can help to explain the process. They can decide beforehand, whom they want to vote for and learn how the ballot works. Thus, it is important.

\subsection{The value of online relationships in spurring people to vote}

The development of modern technologies has undoubtedly contributed to the emergence of an information society, whose awareness of the exercising its electoral rights is gradually increasing. Nevertheless, the question should be asked, whether the introduction of ever newer forms of information technologies, which, on the one hand, facilitate the way of communication and information transfer, and on the other hand, constitute a tool in making political decisions, should be seen as a real measure, being the optimal antidote to numerous social dilemmas, in particular, the low voter turnout, which has been steadily decreasing for many years. At this point, it is worth emphasizing that modern information technologies undeniably affect the shape of democracy itself, and with it the tools that are used within it $^{10}$.

The use of electronic voting certainly generates lower costs for the citizen, however, the average citizen in this way is less and less a member of the political community feeling responsible for the fate of his community, and increasingly becomes only interested in optimizing the individual benefits he/she can achieve. Social media has changed the way people communicate with each other. In previous years, traditional media played a significant role in creating awareness among people, but over period of time social media became an important marketing tool which not only makes people more aware of various matters but also helps to activate them. Politicians are becoming more and more active on social media ${ }^{11}$.

9 More in: Denver D., Hands G. Modern Constituency Electioneering. London: Franc Cass, 1997, pp. 117-122.

10 More in: Porębski L. Więcej, szybciej, latwiej. O radościach i smutkach związanych z elektroniczna demokracją. In: Demokracja elektroniczna. Kontrowersje i dylematy [More, faster, easier. About the joys and sorrows of electronic democracy. In: Electronic democracy. Controversies and dilemmas], Marczewska-Rytko M. (ed.), Lublin: Publishing house UMCS, 2013, pp. 13-31; Marczewska-Rytko M. Elektroniczny wymiar demokracji. Wybrane kwestie In: Demokracja elektroniczna. Kontrowersje i dylematy [The electronic dimension of democracy. Selected issues. In: Electronic democracy. Controversies and dilemmas], Marczewska-Rytko M. (ed.), Lublin: Publishing house UMCS, 2013, pp. 33-47.

11 More in: A Biswas A., Ingle N., Roy M. Influence of Social Media on Voting Behavior. Journal of Power, Politics \& Governance, Vol. 2, No. 2, 2014, pp. 127-155. 


\subsection{Creating well-informed voters}

Creating well-informed voters, while some states have enacted automatic voter registration, as well as implemented policy changes allowing for early voting, absentee ballots, election day registration, and voting at home; a vast majority of voters are still not aware of the policy changes and how they can ease the voting process. A greater number of eligible voters probably participate in elections when the act of voting seems to be important, and when the electoral situation provides a sense that voting is associated with a personal impact on the results of the election, and therefore on the shape of government policies, and when the costs of participation in elections are not high. One may be encouraged to participate in elections if convinced about the value of the participation itself as an act of legitimizing the power, the possibility to really influence its shape, while treating the electoral participation as a civic duty in a democratic society ${ }^{12}$.

\section{Conclusions}

From the above views, however, follows the next question: whether the mere increase in the number of people participating in the election is what it is really about. It should be remembered that lowering the standards of democracy may lead to its collapse or - even worse - to its illusory functioning. Is it not appropriate in this state of affairs to consider J. Schumpeter's opinion that the mere fact of holding elections should be considered sufficient to distinguish a given state as democratic ${ }^{13}$, and then the previously asked questions become irrelevant? On the other hand, should one ignore legal mechanisms contributing to the increase in eligible voters' participation and try to interfere in electoral mechanisms so that the participation of representatives is not a minority representation but a majority one? The attitude of the public towards their participation in political life is related to the level of confidence in the existing political system, existing parties, government institutions and politicians. Declining turnout rates as an expression of deteriorating support for a given political system poses a threat to democracy, because it can lead to the increasing popularity of anti-democratic movements. Decreasing turnout in every election results in a situation where society faces a need to change its lifestyle, reinterpret the role of government, become aware of its role in social and public life. The situation forces a change in behaviour, opinion and attitudes.

\section{BIBLIOGRAPHY}

1. Andre A., Depauw S., Deschouwer K. Issue Uptake in the Shadow of Election. In: BetweenElection Democracy: The Representative Relationship After Election Day, Esaiasson P., Narud H. M. (eds.), ECPR Press, 2013.

12 See Foley E. B. Voters as Fiduciaries. University of Chicago Legal Forum, 2015, pp. 153-192.

13 Schumpeter J. A. Kapitalizm, socjalizm, demokracja [Capitalism, socialism, democracy]. Warszawa: Scientific Publishing House PWN, 1995, p. 312. 
2. Biswas A., Ingle N., Roy M. Influence of Social Media on Voting Behavior. Journal of Power, Politics \& Governance, Vol. 2, No. 2, 2014.

3. CCPR General Comment dated 10 November 1989 No. 18. Available at: https:// www.refworld.org/docid/453883fa8.html [last viewed January 14, 2020].

4. Denver D., Hands G. Modern Constituency Electioneering. London: Franc Cass, 1997.

5. Foley E. B. Voters as Fiduciaries. University of Chicago Legal Forum, 2015.

6. Giżyńska M., Polaczuk P. Compulsory voting: is possible in today’s Poland? Studia Politologiczne, Vol. 32, 2014.

7. Global Parliamentary Report: The Changing Nature of Parliamentary Representation, Denmark: UNDP/IPU, 2012.

8. Hill L. Compulsory Voting in Australia: A Basis for a Best Practice Regime. Federal Law Review, Vol. 32, No. 3, 2004.

9. Human Rights Committee Communication of 30 January 1986 in case Marshall v. Canada (application No. 205/1986).

10. Judgement of the Polish Constitutional Tribunal of 9 March 1988, Ref. No. U 7/87.

11. Kato K. Evaluating Compulsory Voting: Australia in Comparative Perspective. Ann Arbor: ProQuest LLC, 2014.

12. Marczewska-Rytko M. Elektroniczny wymiar demokracji. Wybrane kwestie In: Demokracja elektroniczna. Kontrowersje i dylematy [The electronic dimension of democracy. Selected issues. In: Electronic democracy. Controversies and dilemmas], Marczewska-Rytko M. (ed.), Lublin: Publishing House UMCS, 2013.

13. Matsler S. Compulsory Voting in America. Southern California Law Review, Vol. 76, No. 4, 2003.

14. Porębski L. Więcej, szybciej, łatwiej. O radościach i smutkach związanych z elektroniczna demokracją. In: Demokracja elektroniczna. Kontrowersje i dylematy [More, faster, easier. About the joys and sorrows of electronic democracy. In: Electronic democracy. Controversies and dilemmas], Marczewska-Rytko M. (ed.), Lublin: Publishing House UMCS, 2013.

15. Power T. J. Compulsory for Whom? Mandatory Voting and Electoral Participation in Brazil 1986-2006. Journal of Politics in Latin America, Vol. 1, 2009.

16. Robbins J. S. Introduction: Democracy and Elections. Fletcher Forum of World Affairs, Vol. 21, No. 1, 1997.

17. Schumpeter J. A. Kapitalizm, socjalizm, demokracja [Capitalism, socialism, democracy]. Warszawa: Scientific Publishing House PWN, 1995.

18. Swenson K. M. Sticks, Carrots, Donkey Votes, and True Choice: A Rationale for Abolishing Compulsory Voting in Australia. Minnesota Journal of International Law, Vol. 16, 2007. 